\title{
Traditional Architecture: The Role of Traditional Festival in Islamic Historic District to Achieve Local Community Wellbeing
}

\author{
Arif Budi Sholihah ${ }^{1 *}$, Putu Ayu Agustiananda ${ }^{2}$ Junanah $^{3}$, Wisnu Setiawan ${ }^{4}$ \\ 1,2,3 Department of Architecture, Universitas Islam Indonesia \\ ${ }^{4}$ Department of Architecture, Universitas Muhammadiyah Surakarta \\ $\underline{\text { arif.sholihah@uii.ac.id }}^{{ }^{*}}$,agustiananda@uii.ac.id ${ }^{2}$, junanah@uii.ac.id $^{3}, \underline{w s 238 @ u m s . a c . i d^{4}}$
}

Received: $20^{\text {th }}$ June $2019 \quad$ Final version received: $24^{\text {th }}$ December 2019

The current studies demonstrate how tourism activities have incorporated the role of festival and heritage to address socio-cultural, economic, political, and environmental issues. In the context of Indonesia, the cultural festival has been used to be one medium of Islamic preaching, since the era of Walisongo in the sixteenth century. Several local level festival appears to attract a large number of visitors which later influences the sustainability of the place, including Ya Qowiyyu Festival in Jatinom, Klaten, Central Java. Preserving the tradition for hundreds of years, the local community in Jatinom maintains this cultural practice until the present day. This research aims to explore the dynamics between the festivals of Islamic culture in Indonesia in achieving the local community wellbeing in the context of sustainable development. It utilizes qualitative inquiry that sees there are multiple, socially constructed realities. The technique used was observation and in-depth interviews with open-ended questions. The study demonstrates the success of Ya Qowiyyu Festival in addressing social, economic, and environmental issues in the area. For example, it generates community contentment and provides a financial contribution to stakeholders and local communities that enhance their wellbeing.

Keywords: Community Wellbeing, Traditional Festival, Islamic Historic District

\section{INTRODUCTION}

The worldwide experience notes that intangible cultural events have become one way to maintain cultural heritage in a massive way, which often incorporate arts and performances, rituals, and also festivals (S. Kim, Whitford, \& Arcodia, 2019). In particular, cultural festivals often refer to artistic and cultural performances that are now a worldwide tourism phenomenon (Chacko \& Schaffer, 1993; Getz, 1991; Grant \& Pallwoda, 1998). The creativity produced in cultural festivals has emerged as an enhancement for a city to posit itself compared to other cities in the world (Richards, 2001). This contributes to building the uniqueness of the place.

In its development, festivals have various meanings that pinpoint to cultural activities (cultural performance) (Heriyawati, 2005), cultural ritual activities to show the identity of the community (HS Salim, 2005), as well as activities to show the cultural heritage of a community (Yolal, Gursoy, \& Uysal, 2016). In the present era, the purpose of the festival is not only related to culture and identity but also extended to the promotion of a city/village, tourists attraction, and cultural entertainment provision to the local community which influence on quality of life improvement (Cudny, Korec\&Rouba, 2012, in Yolal et al., 2016). In addition to that, festivals often take place in the historical places which incorporate heritage built environment (Ma \& Lew, 2012). The atmosphere of heritage offers a unique experience for visitors away from their daily life. In fact, the uniqueness and quality of festivals significantly influence the success of the festival. Heritage built environment becomes a strategy to secure authenticity; heritage brings a strong context to the events. This helps the events to survive by maintaining the tourists' expectations from time to time.

Tourism activities relying on the festival and heritage would generate beneficiaries not only from the historical dimensions, but also in term of economic, socio-cultural, political, and environmental contexts (Ma \& Lew, 2012). Festivals are analysed in the context of various dimensions from place-making strategies to geopolitical issues; festivals even touch upon the 
discussion from sustainable (Perry, Ager, Sitas, \& Perry, 2019) and its contribution to wellbeing in general.

Table: The Dimension of Community Wellbeing and Sustainable Community

\begin{tabular}{|c|c|c|c|}
\hline No & Dimension & $\begin{array}{c}\text { Community } \\
\text { Wellbeing }\end{array}$ & $\begin{array}{l}\text { Sustainable } \\
\text { Community }\end{array}$ \\
\hline 1 & Environment & $\begin{array}{l}\text { Environmental } \\
\text { quality }{ }^{1,3,6} \text {, } \\
\text { sustainable } \\
\text { environment } \\
\text { (built and } \\
\text { natural) }{ }^{4,6}\end{array}$ & $\begin{array}{l}\text { Sustainable } \\
\text { development, } \\
\text { environmental } \\
\text { quality, } \\
\text { disaster } \\
\text { resilience }\end{array}$ \\
\hline 2 & Economic & $\begin{array}{l}\text { Economic } \\
\text { prosperity }^{5} \text {, } \\
\text { income } \\
\text { sufficiency }^{1,6} \text {, } \\
\text { resilient local } \\
\text { economy }{ }^{4} \text {, } \\
\text { employment } \\
\text { and business } \\
\text { opportunities }^{6}\end{array}$ & $\begin{array}{l}\text { Sustainable } \\
\text { economic } \\
\text { wellbeing, } \\
\text { economic } \\
\text { vitality }\end{array}$ \\
\hline 3 & Social & $\begin{array}{l}\text { Social equity, } \\
\text { community } \\
\text { spirit, } \\
\text { neighborhood } \\
\text { safety, informal } \\
\text { social } \\
\text { interaction, } \\
\text { trust and } \\
\text { reciprocity } \\
\text { community }\end{array}$ & $\begin{array}{l}\text { Social } \\
\text { sustainability, } \\
\text { social and } \\
\text { inter- } \\
\text { generational } \\
\text { equity, active } \\
\text { participation }\end{array}$ \\
\hline 4 & Cultural & $\begin{array}{l}\text { Culturally rich } \\
\text { and vibrant } \\
\text { community }^{4} \text {, } \\
\text { cultural } \\
\text { vitality }^{5} \text {, } \\
\text { spiritual }^{2} \\
\text { quality }^{2}\end{array}$ & $\begin{array}{l}\text { Cultural } \\
\text { sustainability }\end{array}$ \\
\hline 5 & Attachment & $\begin{array}{l}\text { Place } \\
\text { attachment }^{1,6} \text {, } \\
\text { community } \\
\text { attachment }^{3}\end{array}$ & $\begin{array}{l}\text { Sustainable } \\
\text { community }\end{array}$ \\
\hline 6 & $\begin{array}{l}\text { Services } \\
\text { (incl. Health) } \\
\text { and Facilities }\end{array}$ & $\begin{array}{l}\text { The appearance } \\
\text { of built } \\
\text { environment }^{1,6} \text {, } \\
\text { infrastructure }{ }^{6} \text {, } \\
\text { services and } \\
\text { facilities }^{6}\end{array}$ & $\begin{array}{l}\text { Environmental } \\
\text { sustainability, } \\
\text { quality of life }\end{array}$ \\
\hline & \multicolumn{3}{|c|}{$\begin{array}{l}\text { source: summarised from various references } \\
\text { (Christakopoulou, S., Dawson, J., \& Gari, } \\
\text { 2001), (Sirgy, M. J., Widgery, R. N., Lee, D. } \\
\text { J., \& Yu, 2010), (Forjaz et al., 2011), (Morton, } \\
\text { A., \& Edwards, 2012), (Al-Haydari, 2011), } \\
\text { (McCrea et al., 2014) }\end{array}$} \\
\hline
\end{tabular}

The concept of wellbeing has been used interchangeably with quality of life, happiness, and life satisfaction (McCrea, Walton, \& Leonard, 2014). Measuring wellbeing in a community is vital to know how that community is faring; it, therefore, provides critical information for decision-making regarding sustainable development in regional communities (Al-Haydari, 2011). The definition of well being in community-level refers to the satisfaction of the local people with the local place, how they attach to it, how the social and physical environment quality is, and the services and facilities provided (Forjaz et al., 2011). According to (Wiseman \& Brasher, 2008, p.358) 'Community wellbeing is the combination of social, economic, environmental, cultural, and political conditions identified by individuals and their communities as essential for them to flourish and fulfill their potential.' The discussion of community wellbeing covers at least five dimensions: environment, economic, social, culture, place attachment, and services, in comparison with the dimension of sustainable development from the tourism industry point of view, as summarised in Table 1.

Sustainable development is generally defined as the 'development that meets the needs of the present without compromising the ability of future generations to meet their own needs,' as coined by the Brundtland Report in 1987 (S. Kim et al., 2019). In the context of tourism development, the industry has acknowledged the sustainable development approach into its practices, for example, in a relationship with sociocultural and environmental issues. On the other hand, the definition of sustainable tourism seems to vary due to a wide range of interpretations, similarly with the case of 'sustainable development.' However, a short definition has been proposed that 'sustainable tourism activities must meet the social and economic of today needs without result in the significant natural and cultural environment for the future generation' (S. Kim et al., 2019). This definition is further elaborated into three dimensions summarised by the World Tourism Organization (UNWTO, 2019): (1) environment: optimal use of 
environmental resources as key element in tourism development; (2) social: sociocultural authenticity of communities, built and living cultural heritage and traditional values, and inter-cultural understanding and tolerance; (3) economic: providing long-term socio-economic benefits to all stakeholders, stable and contributing to poverty alleviation.

In response to the idea of sustainable tourism development and community wellbeing, various researches on cultural festivals mainly focus on evaluating the impact of festival existence on the economic impact and success of the festival itself as a cultural activity (Bracalente, Chirieleison, Cossignani, \& Ferrucci, 2011; Crompton, 2001; K. Kim \& Uysal, 2003; Tohmo, 2005; Tyrrell \& Ismail, 2005). The economic and political approach is often used, particularly in marketing the festival or socio-cultural events, which sometimes overshadow the socio-cultural and environmental context (Ma \& Lew, 2012). So far, the success of a festival or event is generally measured by its economic contribution to stakeholders, local communities, and the region. In line with this, little empirical research has been focusing on sociocultural impacts on society (Pavluković, Armenski, \& Alcántara-Pilar, 2017; Rao, 2001). This phenomenon leads to an argument to explore the value of cultural festivals within a more holistic approach to sustainable development (Perry et al., 2019) and its impact on the community wellbeing on a long-term basis.

\subsection{Cultural Festivals in Indonesian context: Islamic Culture Festival}

Similarly, with the global trend, the tourism industry in Indonesia has become more and more in incorporating the activities with cultural festivals. In fact, Indonesia has been promoting tourism development as one of the main national commodity. Various festivals in the form of ceremonies, parties, or celebrations have been known and rooted in various ethnic communities in Indonesia. The cultural festival evolves into an instrument for promoting the local culture and heritage to the global community (Sakitri, 2018). In the Indonesian context, traditional streets emerged as cultural spaces in urban areas, space for parades, and festivals. More specifically, festival in Indonesia can be classified in several types of rites or activities, including (1) purification rite, (2) rite of transition, (3) rite reversal, (4) party, symposia, (5) exhibition, (6) drama, and (7) rite of exchange (HS Salim, 2005).

Having the biggest Muslim population in the world, the discussion of heritage and conservation in Indonesia often links to the position of Islam culture (Koentjaraningrat, 1944). For example, the history notes that the Islamic culture and local culture in Indonesia has been mingled and blended over centuries, one of them through literature, such as Serat Centhini (Junanah, 2009). Islam in Indonesia is the result of the da'wah process that is carried out culturally so that in a short time can be accepted, developed, spread, and embraced by the majority of Indonesian people. Islam in Indonesia enters subtly without violence until it can be seen that Islamic cultural values have integrated into the local cultural values of the country in various forms including in the form of tradition, art, culture, and architecture (Miharja, 2014). Islam is a dominant force in Javanese religious beliefs and rituals, shaping the character of social interaction and everyday life in all segments of Javanese society (Woodward, 1989: 3 in Kim, 2013). The meeting of Islam with local culture or inter-religious teachings in Indonesia resulted in the adoption, disposal, and acculturation that took place in a high tolerance atmosphere (Amrullah, 2015).

In the era of Walisongo in the sixteenth century, Islam is spread through Wayang Kulit (Shadow Puppet) as a medium of Islamic teachings by Sunan Kalijogo, as well as Wayang Golek Menak (Menak Puppet Show) taken a source from Arabic and Persian stories used as a medium of Islamic preaching (Istanti, 1996). Even in the era of the Demak Kingdom, which received support from the Walisongo, there was a meeting place between local cultural figures of Java (priyayi) with the Wali (Guardian). This direct contact fosters acculturation between Javanese traditions and culture with elements of religion and Islamic culture (Porbatjaraka, 1957 in Istanti, 1996). Furthermore, the Wali and Kyai (clerics) also introduce Islam through cultures such as songs containing Islamic da'wah, customs, culinary, building (architecture), costumes, and traditions (Handayani N.M., 2015), including Ya Qowiyyu Festival in Jatinom Klaten, probably the biggest festival 
associated with Islamic and Javanese culture in a rural area in the Central Java.

\subsection{The emerging issues of the cultural festival $s$}

A number of studies on cultural festivals in Indonesia present insufficient discussion. A part that festivals have become an opportunity to promote local culture and heritage, the events sometimes receive less support from the government, particularly in the rural area (Sakitri, 2018). Insufficient support from the government could slowly make traditional festivals to fade and even extinct in the future (Sholihah, 2016). Similar issues have appeared in the event of Ya Qowiyyu Festival in Jatinom, Klaten. Not only it lacks formalized government contribution, but also the community struggles in maintaining the balance between economic, socio-cultural, and environmental atmosphere during and after the events. In short, a general question presents in arguing how the event would be beneficial for the community in the long-term from a holistic approach. For this reason, this research aims to explore the dynamics between the festivals of Islamic culture in Indonesia in achieving the local community wellbeing in the context of sustainable development.

\section{RESEARCH METHODS}

The research utilizes qualitative inquiry that sees there are multiple, socially constructed realities (Groat \& Wang, 2002). The strategy of this research is a case study strategy that investigates a single setting phenomenon within its real-life context, especially when the boundaries between phenomenon and context are not evident (Yin Robert, 1994).

The data collection has been done through field observations before the festival, throughout the festival processions (one week), and after the festival to get text data from in-depth interviews. The interview technique used is an open-ended question with several main questions compiled in the interview questions sheet. Respondents interviewed were local people with categories, 1) local people of Jatinom, almost all interviewees were born in Jatinom, and 2) directly involved in the festival processions for more than five years to ensure familiarity with the activities and benefits obtained from this festival.

Secondary data is obtained from several sources, such as journals, books, newspapers, and other publications, as well as additional relevant information. The analysis is carried out inductively to get robust and valid results that combine theories and literature reviews, as well as primary and secondary data before analyzing research findings.

The analysis is done by inductive techniques followed by the concept of (Kvale, 2007), which is: coding and categorizing texts, condensation, and interpretation of meaning. The findings also then are related to the community wellbeing dimension, which in the context of this study revealed six themes that emerged and will be discussed in results and discussions, presented in Table 2 as follows:

Table 2: Emerging Themes from the Data Collection in the Context of Ya Qowiyyu Festival

\begin{tabular}{lll}
\hline Theme & $\begin{array}{l}\text { Community } \\
\text { Wellbeing } \\
\text { Dimension } \\
\text { (CWD) }\end{array}$ & Emerging Themes \\
\hline $\mathrm{T}-1$ & Socio & $\begin{array}{l}\text { Festival and } \\
\text { Community } \\
\text { Contentment }\end{array}$ \\
\hline $\mathrm{T}-2$ & Economic & $\begin{array}{l}\text { Festival and Economic } \\
\text { Development }\end{array}$ \\
\hline $\mathrm{T}-3$ & Environment & $\begin{array}{l}\text { Festival and } \\
\text { Environmental } \\
\end{array}$ \\
& & Sustainability \\
\hline
\end{tabular}

\section{FINDINGS AND DISCUSSIONS}

\subsection{Ya Qowiyyu: Traditional Festival in Islamic Historic District}

Jatinom is an Islamic historic district in Klaten, the place where Kyai Ageng Gribig Islam led the da'wah, the practice of conveying the message of Islam. He was a descendant of Prabu Brawijaya $\mathrm{V}$ from Majapahit, whose real name is East Wasibagno (Syarifah, 2014). He went wandering west, leaving Majapahit to seek true knowledge and to get the happiness of the world and the hereafter. This village was formed when Kyai Ageng Gribig built a hermitage under the teak tree (pohon Jati), which then became the name 'JatiEnom', or later known as 'Jatinom' (Handayani N.M., 2015). At the time, Kyai Ageng Gribig had a close relation with the Sultan Agung the King in Mataram, Central Java in the Sixteenth Century and he gave Kyai Ageng Gribig a perdikan land (tax free traditional land) called 'Perdikan Mutihan' and 
the Kyai built mosques and boarding school (Pondok Pesantren) (Immanuel, Lee, Maizida, \& Pabbajah, 2018).

The tradition of Ya Qowiyyu festival in Jatinom began after Kyai Ageng Gribig returns from Hajj in Mecca in 1539 AD. He brought two Arab's cakes, which then cut and shared by his students but not enough for them. They then cooked Apem, with local ingredients, i.e., rice flour and coconut as substitutes of the Arab's cakes, and after that, they shared the Apem also their neighbors. The name of Apem is believed to be 'Afnafwun', which means 'blessing' ((Immanuel et al., 2018; Handayani N.M., 2015). However, it was too tricky for the Javanese to pronounce an Arabic word, so that they called the cake as Apem (Immanuel et al., 2018). The Apem cakes made by the students were then accepted by Kyai Ageng Gribig. After that, they prayed together to ask 'berkah' (blessing) from Allah (God) (Amaliyah, 2015) and as an effort to maintain security and peace (Islami, 2014). Berkah itself is from the Arabic word 'barokah' means something that gives benefits, and they distribute the cake to the public/local people. That is how the tradition began. The sharing Apem became the tradition and ritual named Ya Qowiyyu or Sebaran Apem or Apeman.

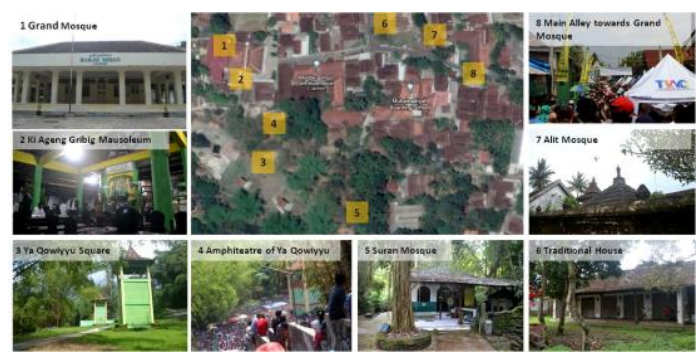

Figure 1: Jatinom Historic Sites and Ya Qowiyyu Festival

Architecturally, the formation of Jatinom district is influenced by Javanese urban main elements (Figure 1), namely the Mosque, Market, City Square (Alun-alun), and the center of government (in this case, the Ki Ageng Gribig house), which are located next to Jatinom mosque. Jatinom is a representation of a suburban area in Java, which is supported by agricultural activities, creative industries (Lurik and Batik), and trading (Jatinom Market).
Until now, the existence of various sites in the Jatinom related to the development of the region still exists. For example, the Jatinom community still preserves the values and intangible heritage (such as the Ya Qowiyyu festival). However, the creative industry producing Lurik and Batik, which once made Jatinom a famous region, is now declining. Many of the houses that used to be a production house for the Lurik and Batik have become empty. Jatinom is more populated by older generations, while many young people move to other places to become traders or become teachers and government employees.

\subsection{The Ya Qowiyyu Processions}

Each year in the middle of Hijriya Safar month, Ya Qowiyyu festival held to remind the story of Kyai Ageng Gribig and the Apem sharing to get a blessing that is believed by the participants. There is also a specific prayer recite during the festival that is 'Ya qowiyyu qowwina wal muslimin ya qowiyyu ya rozaq warzuqna wal muslimin' meaning 'Oh strong God, give us strength and also to the entire Moslem community, Lord, the most Powerful and most Critical Grantor, provide critical grantor to us and also to the entire Muslim community (Immanuel, 2018).' This tradition has been going on for hundreds of years; it continues to be held by the people of Jatinom Village until the present era. Thousands of visitors not only from Klaten but also from other regents in Java visit this festival. This festival is increasingly visited, not only for the worshipper from Central Java but also from East and West Java and becoming a religious tourist destination for the general public.

The procession of Ya Qowiyyu festival is growing over the years. Now, a series of events last for seven days (a week) supported by various stakeholders as performers, as presented in Figure 2. They involve school children for street carnival, traditional art such as Javanese dance, Kethoprak, Wayang Kulit, and so on are performed in several spots around Jatinom. Also, the other interesting part is the Apem, which is then used as Jatinom special food can be purchased during the processions at outlets along the festival path, opened by local women of Jatinom. 


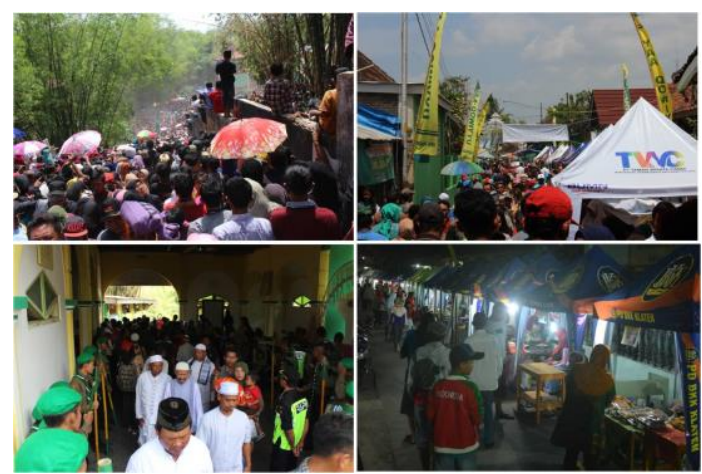

Figure 2: The Ya Qowiyyu Processions

The peak time of the event is the Apem distribution held with a procession from the subdistrict office paraded to the Alit Mosque, then to the Great Mosque of Jatinom, and ended in Oro-oro Ya Qowiyyu (Ya Qowiyyu square), which is located on the south of the mosque. Thousands of people will fight to get the Apem spread by the Jatinom community with traditional costumes resembling Kyai Ageng Gribig's students. Some additional events are including the presence of Gunungan Lanang and Wadon containing Apem, which represent the prostrations of gratitude to God.

The actors involved in the procession are also increasingly diverse, namely the local Jatinom community who are guardians of the tradition, Jatinom district and regional government, and even now also the private sector. Since the procession in 2018, the festival also involves the PT. Taman Wisata Candi Borobudur, a stateowned company that is aggressively promoting tourism in Central Java.

\subsubsection{Theme 1: CW Social Dimension: Ya Qowiyyu Festival and Community Contentment}

A sense of pride is the reason why the residents get involved regularly and loyally as the organizing committee of this event. In fact, for those who migrated out of town for jobs, this event becomes significant, so they are willing to take time off from work and go home every year. They feel proud and happy as if they were $\mathrm{Ki}$ Ageng Gribig's students, for they could be able to preserve what had become a cultural heritage.

Several weeks before Month Safar comes, the community begins cleaning and even painting the house, preparing themselves and the environment to receive relatives and visitors from outside Jatinom. It demonstrates the aspirations of the community to welcome Month Safar, not just those of individuals.

They admitted that the Ya Qowiyyu festival brought them a sense of happiness because it was always crowded with happy children and enthusiastic women watching the entire series of events, as quoted in the interview:

'I feel very happy when the month of Safar is almost coming; there is a sense of joy that welled up, very happy, people left their work for a while to prepare for the festival, that's what I also do, I experience it myself every year' (Epta, 2019).

Many art and cultural attractions are performed to years as a series of celebrations of Yaa Qowiyyu, like traditional dances, Ketoprak, Macapat, and others, involving the local community and people from outside Jatinom. They feel happy and entertained, especially on the Eve of Midodaren and the Day of Sebaran Apem as the peak event. This is what they called 'spectacle' (tontonan) and 'guidance' (tuntunan). Through the tomb pilgrimage, they started to know Ki Ageng Gribig, who has been credited with spreading Islam hundreds of years ago, so that they sincerely prayed for and pleaded for forgiveness to God for his mistakes.

Through the tomb pilgrimage, they found out that in Jatinom $\mathrm{Ki}$ Ageng Gribig has been credited with spreading Islam hundreds of years ago, so that they sincerely prayed for and pleaded for forgiveness for their mistakes when they were there. This finding is in parallel to the previous findings that festival and special event can be regarded as community events that contribute to community cohesiveness and create social incentives for the local community (Gursoy, Kim, \& Uysal, 2004); the festival has a positive impact on a community's quality of life by providing an opportunity to escape from daily routines and to socialize with family and friends within the larger community (Earls, 1993).

The figure of Ki Ageng Gribig that is embedded in the hearts of local residents encourages their appreciation of spiritual values inherited from him as one of God's wali (guardians). Some respondents said that this tradition motivated them to be more pious. The story of how Kyai Ageng Gribig contributed to the spread of Islam in the region became their inspiration. People in Jatinom generally still feel a strong attachment to the figure of Ki Ageng Gribig, as mentioned by a respondent. 
'I really appreciate Ki Ageng Gribig's role to Islamized Jatinom, there is a distinct impression for me, because I think it is difficult to do, that is why I want to help preserve it and continue his struggle, that is my motivation to get involved in this festival'(Rifai, 2018).

Some respondents acknowledge that events of Quran recitation and Ya Qowiyyu ceremony indeed contain spiritual values to the local communities. Moreover, the ceremonies, including the distribution of Apem and leather puppet performance delivered as a direct 'spectacle' (tontonan), can also provide an indirect spiritual 'guidance' (tuntunan). Other respondents admitted that visitors from other cities, including Magelang, Kudus, and Jepara, came to Jatinom for attending Ya Qowiyyu ceremony as well as for a religious pilgrimage.

However, some respondents do not agree that the ceremony could increase the spiritual quality of the citizens. One of them argued that the activities on Friday night before the peak event were only attended by the tombs caretakers and others who were involved in the event organization. Outside of the main events, the local community conducted a dhikr (a rhythmic repetition of the names of God) together every Friday Legi (one of day in the five-days cycle based on Javanese calendar), but it was admitted in part that spiritual improvement was very personal, because it depended on each individual personality.

The other respondent thinks that the types or characters of each person are different: there are those who are obedient, abangan (partlybeliever), or non-Muslim. Furthermore, they feel that they have the responsibility to strengthen the understanding of the pilgrims, that they were forbidden to ask anything to the buried, but prayed only to Allah, as taught by Ki Ageng Gribig before he died. Furthermore, one of them also argues that the tomb pilgrimage would actually remind them of death and thus make them correct their deeds in life.

The findings of this study are parallel with the findings of a study of the Ijebu Ode's Ojude Oba Festival in Nigeria when people come to celebrate and reconnect to their roots, reflect religious, social, and cultural responsiveness to the part of the people (Fahm, 2015). However, the latest developments in the series of $\mathrm{Ya}$ Qowiyyu festivals also involve a variety of supporting events; these did not change the essence of the Ya Qowiyyu festival, which embodies the local culture fulfilled with spiritual and religious values.

\subsubsection{Theme 2: CW Economic Dimension: Ya Qowiyyu Festival and Economic Development}

During the series of Ya Qowiyyu festival, the respondents mostly revealed that they obtained economic benefits as well as religious advantages. In terms of the economy, it is clear that it has a positive impact on the local community and the people from outside Jatinom. There is a clear division of labor between men and women: men take care of the compound of the tombs and organize festivals, while the women sell Apem.

The first income was obtained from the sale of Apem, a traditional cake distributed and sold on the day of the ceremony throughout the festivals. Not only local people received the income but also those people who lived outside the Jatinom area and came as an Apem seller. Residents who own large yards can rent it to the outsiders selling Apem around the mosque. Anyone is allowed to make Apem, even those people coming from outside the village. Jatinom residents maintain the standard recipes and procedures for making such a cake. It is meant to maintain authenticity and the uniqueness of Jatinom. By ensuring the use of equal recipes and through specific procedures, local residents can check the appropriateness of Apem taste that was produced outside the village. The $\mathrm{Ya}$ Qowiyyu ceremony certainly offers additional income to the local people.

The second income came from visitors' contributions to the $\mathrm{Ki}$ Ageng Gribig tomb compound. Donations obtained during the $\mathrm{Ya}$ Qowiyyu festival were handed to the management, some of which were distributed to the members a remuneration, and some were used as the committee's cash deposit.

The respondents do not admit any commercialism, since the tomb compound caretakers generally behave 'nrimo' (sincere) and show 'handarbeni' (sense of belonging), believing that such a deed will ensure the blessing from God as stated in the interviews:

'Basically we, the Jatinom people, do not want to commercialize this festival, although indirectly it does raise the regional economy. We feel we have handarbeni (sense of belonging) to this 
activity, even if we have to donate to organise it, we believe there is a good fortune and blessings in here. (Nugroho, 2018)

Considering that religion has always been prioritized in this village, it is necessary to develop Ya Qowiyyu religious tourism in Jatinom. Without having to be commercial, Ya Qowiyyu appears to be a successful festival or event as (Douglass, M. \& Daniere, 2009) states, which are generally measured by its economic contribution to stakeholders and local communities of the region.

However, the interview also revealed that all the costs of organizing a festival were mainly from community donations. People from various regions who feel they are 'close' to Jatinom people and Kyai Ageng Gribig. Such as the Wonolelo and Pandanaran Islamic Boarding Schools in Sleman, which were established by the students of Kyai Ageng Gribig always give donations for this activity. Also, a year of donations from the pilgrims of the Kyai Ageng Gribig tomb was collected by the manager and then used mainly for this festival. It shows that the festival's economic benefits for festival organizers are minimal.

Assistance from the local government has also not been significant enough to help fund the festival. Even though the local government has funds for this activity, it is only focused on supporting activities, such as student carnivals and performance arts, apart from the main processions of the festival. The manager of Ya Qowiyyu was burdened with filling the locallygenerated revenue to the government in the amount of 4 million rupiahs in 2018. It can be interpreted that the community is quite independent and resilient in organizing the festival, especially in terms of funding since it is proved the sustainability of the festival for more than five hundred years.

On the other hand, even though this festival has not provided sufficient economic benefits, the respondents still feel that the festival is better not to be commercialized. So far, they have not sought funding from sponsors of commercial products. Everything is voluntary in aid from the people who contribute and donate. The values of sincerity and sense of belonging towards Festival Ya Qowiyyu can be said to still survive in this era of capitalism.
The findings of this study are contradictory to previous studies that examined the economic contribution of festivals to the local economy (Gursoy et al., 2004). However, these findings are in parallel with studies that emphasize the social benefit aspects of a festival. Rao (2001) suggests that festivals have public-good aspects beyond revenue-generating because they provide a place where the community can get together and participate in mutually enjoyable activities. They also play an essential role in creating trust and cohesiveness among community members (Chwe, 1998).

\subsubsection{Theme 3: CW Environmental Dimension: Ya Qowiyyu Festival and Environmental Sustainability}

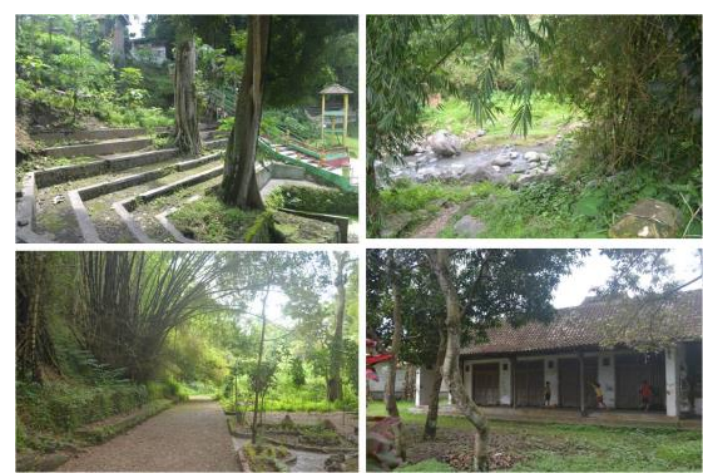

Figure 3: Rural and Cultural Landscape of Jatinom

One of the noticeable potentials in Jatinom is rural and cultural landscape. Near the historic Kyai Ageng Gribig site, there are bamboo forests that are still very natural and of good quality, as well as clean rivers that are typical in the tropics, as seen in Figure 3. This natural environment has not been widely used, and the conditions are now relatively good and well-maintained. Public respect for the figure of Kyai Ageng Gribig also plays a role in caring for and preserving the existing nature, especially also there is a cave where Kyai Ageng Gribig lives as an ascetic and until now as one of the sites most visited by the pilgrims. At the peak of the Ya Qowiyyu festival, thousands of people attended, bringing potential waste and environmental damage. However, this does not seem to be an obstacle because the manager has provided much anticipation. However, in some quite steep locations, namely at the amphitheater in Oro-oro Ya Qowiyyu is a little prone to landslides if there are too many visitors. 
Regarding the use of nature, in one interview, a respondent who was a local artist had the idea of making musical instruments from bamboo and stone. For him, it is very important for Jatinom to have an artistic and cultural identity, as saying:

'I hope that the art and cultural heritage of Jatinom are maintained and unique, for this reason we as young people strive creatively to develop it with existing potential, such as by developing the Klotekan bamboo and stone festival' (Ikram, 2018).

Apart from the natural environment, another potential is traditional architecture in Jatinom with a Javanese Limasan style building with a large yard. This cultural landscape is an area for children to play, something that might have been difficult to find elsewhere.

\section{CONCLUSION RECOMMENDATIONS}

AND

The study intends to analyse the role of $\mathrm{Ya}$ Qowiyyu festival in achieving the local community wellbeing. This festival has been going on for more than 500 years to commemorate the spread of Apem carried out by Kyai Ageng Gribig together with his students in the 16th century. The festival, which is also a da'wah media, becomes a ritual for some visitors and a spectacle for some others. Several important points appear regarding the role of this festival, related to the community wellbeing and sustainability issues. First, the Ya Qowiyyu festival provides a sense of pride and sense of happiness for the local community; for this reason, they always get involved regularly and loyally as the organizing committee of the event. Through the Ya Qowiyyu festival, the community felt that they had social and emotional attachments; in this case, Kyai Ageng Gribig and his students were the most respected figures of the place. This festival, in general, also motivated the community to be more pious.

The second finding relates to economic benefits. Local people generally benefit from good sales during the event. However, in terms of organizing the festival, everything depends on community donations. The program, which lasts for one week, requires no small amount of funds. They set aside funds from donations from the pilgrims for one year and assistance from many parties, minus the regional government. Even though this festival has not provided enough economic benefits, the respondents still feel that the festival is better not to be commercialized. It can be said that the social benefit of this event is more significant, the community is quite independent and resilient in the implementation of the festival, especially since it has proven that the festival has lasted more than 500 years.

The third finding is related to environmental sustainability. The natural and cultural heritage in Jatinom is protected for the community respect to the central figure, Kyai Ageng Gribig. In the context of infrastructure and facilities, the government helps to improve its quality, considering that at the peak of the event, thousands of people will attend the event so that they need more adequate facilities.

The future challenge is how to develop the Ya Qowiyyu festival by involving local community actors, the government, and donors (from the private sector) without degrading the values that need to be preserved. Starting from the involvement of local government and Tourism State Company (TWC) in 2018, it can be seen as a double-edged sword. On the one hand, it will provide economic benefits for both the local government and the local community, but on the other hand, it may also endanger the natural, environmental, and socio-cultural sustainability of the community if it is not carefully maintained and safeguarded.

\section{REFERENCES}

Al-Haydari, D. (2011). Community Well-being: What is it and What Does it Mean for Projects and Local Communities?

Amaliyah, E. I. (2015). Relasi Agama Dan Budaya Lokal: Upacara Yaqowiyyu Masyarakat Jatinom Klaten. Fikrah: Jurnal Ilmu Aqidah Dan Studi Keagamaan, 3(1), 37-56. https://doi.org/10.21043/FIKRAH.V3I1.18 25

Amrullah, M. . (2015). Epilog: Agama dan Budaya Lokal di Indonesia. In The American Institute for Indonesian Studies, LABEL -UIN Sunan Kalijaga dan AIFIS.

Bracalente, B., Chirieleison, C., Cossignani, M., \& Ferrucci, L. (2011). The economic impact of cultural events : the Umbria Jazz music festival. (June 2015). https://doi.org/10.5367/te.2011.0096 
Chacko, H. E., \& Schaffer, J. D. (1993). The evolution of a festival: Creole Christmas in New Orleans. Tourism Management, 14(6), 475-482.

Christakopoulou, S., Dawson, J., \& Gari, A. (2001). The community well-being questionnaire: Theoretical context and initial assessment of its reliability and validity. Social Indicators Research, 56(3), 321-351.

Chwe, M. S.-Y. (1998). Culture, circles, and commercials: Publicity, common knowledge, and social coordination. Rationality and Society, 10(1), 47-75.

Crompton, J. L. (2001). A Guide for Undertaking Economic Impact Studies : The Springfest Example. 40(AUGUST), 79-87.

Douglass, M. \&Daniere, A. (2009). Urbanization and Civic Space in Asia. In M. Daniere, A., Douglass (Ed.), The Politics of Civic Space in Asia. USA: Routledge.

Earls, Z. (1993). First night celebration: building community through the arts. Festival Management and Event Tourism, 1(1), 3233.

Fahm, A. O. (2015). Ijebu ode's ojude oba festival: Cultural and spiritual significance. SAGE Open, 5(1). https://doi.org/10.1177/2158244015574640

Forjaz, M. J., Prieto-Flores, M.-E., Ayala, A., Rodriguez-Blazquez, C., FernandezMayoralas, G., Rojo-Perez, F., \& MartinezMartin, P. (2011). Measurement properties of the Community Wellbeing Index in older adults. Quality of Life Research, 20(5), 733-743.

Getz, D. (1991). Festivals, special events, and tourism. Van Nostrand Reinhold.

Grant, D., \& Pallwoda, S. (1998). Segmenting Alberta arts and festival consumers: part 1: overview of the arts consumer. Festival Management and Event Tourism, 5(4), 207-220.

Groat, L., \& Wang, D. (2002). (2013). Architectural Research Methods (Second Ed.). United State of America, Canada: John Wiley \& Sons, Inc., Hoboken, New Jersey. Retrieved from Wiley. Com/Architecture.

Gursoy, D., Kim, K., \& Uysal, M. (2004). Perceived impacts of festivals and special events by organizers: An extension and validation. Tourism Management, 25(2), 171-181. https://doi.org/10.1016/S02615177(03)00092-X
Handayani N.M. (2015). Sebar Apem "Yaa Qowiyyu." Surakarta.

Heriyawati, Y. (2005). Festival sebagai Kekuatan Budaya. Gong: Sorak Sorai Festival, pp. 18-23.

HS Salim, H. (2005). Festival: Mengantar Tradisi Menjemput Modernitas. Gong: Sorak Sorai Festival, pp. 8-11.

Immanuel, J. M., Lee, G., Maizida, K., \& Pabbajah, T. (2018). The Roles of Muhammadiyah in Shifting Apeman Ritual through State Power and Society. DINIKA: Academic Journal of Islamic Studies, 3(2).

Islami, M. E. N. (2014). Simbol dan Makna Ritual Yaqowiyu di Jatinom Klaten. Jurnal Media Wisata, 12(2), 102-115.

Istanti, K. Z. (1996). Wayang Golek Menak sebagai Media Dakwah Islam. Jurnal Humaniora, (3).

Junanah. (2009). Kata Serapan Bahasa Arab dalam Serat Centhini, Disertasi Doktor. UIN Syarif Hidayatullah Jakarta.

Kim, H.-J. (2013). Reformist Muslims in a Yogyakarta village: the Islamic transformation of contemporary socioreligious life.

Kim, K., \& Uysal, M. (2003). Perceived socioeconomic impacts of festivals and events among organizers. Journal of Hospitality \& Leisure Marketing, 10(3-4), 159-171.

Kim, S., Whitford, M., \& Arcodia, C. (2019). Development of intangible cultural heritage as a sustainable tourism resource: the intangible cultural heritage practitioners , perspectives perspectives. Journal of Heritage Tourism, 14(5-6), 1-14. https://doi.org/10.1080/1743873X.2018.15 61703

Koentjaraningrat. (1944). Kebudayaan Jawa. Jakarta: Balai Pustaka.

Kvale, S. (2007). Analyzing interviews. Doing Interviews, 102-120.

Ma, L., \& Lew, A. A. (2012). Historical and geographical context in festival tourism development. Journal of Heritage Tourism, 7(1), 13-31. https://doi.org/10.1080/1743873X.2011.61 1595

McCrea, R., Walton, A., \& Leonard, R. (2014). A conceptual framework for investigating community wellbeing and resilience. Rural Society, 23(3), 270-282.

Miharja, D. (2014). Persentuhan Agama Isam dengan Kebudayaan Asli Indonesia. MIQOT: Jurnal Ilmu-Ilmu Keislaman, 38(1). 
Morton, A., \& Edwards, L. (2012). Community wellbeing indicators: Survey template for local government. NSW:

Pavluković, V., Armenski, T., \& Alcántara-Pilar, J. M. (2017). Social impacts of music festivals: Does culture impact locals' attitude toward events in Serbia and Hungary? Tourism Management, 63, 4253.

https://doi.org/10.1016/j.tourman.2017.06. 006

Perry, B., Ager, L., Sitas, R., \& Perry, B. (2019). Cultural heritage entanglements: festivals as integrative sites for sustainable urban development. International Journal of Heritage Studies, 1-16. https://doi.org/10.1080/13527258.2019.157 8987

Rao, V. (2001). Celebrations as social investments: Festival expenditures, unit price variation and social status in rural India. Journal of Development Studies, 38(1), 71-97.

Richards, G. (2001). Cultural attractions and European tourism. Cabi.

Sakitri, G. (2018). Local community engagement in a festival in Indonesia. International Journal of Culture, Tourism and Hospitality Research, 12(1), 29-46.

Sholihah, A. B. (2016). The Quality of Traditional Streets in Indonesia. University of Nottingham, United Kingdom.

Sirgy, M. J., Widgery, R. N., Lee, D. J., \& Yu, G. B. (2010). Developing a measure of community wellbeing based on perceptions of impact in various life domains. Social Indicators Research, 96(2), 295-311.

Syarifah, S. A. (2014). Nilai-Nilai Pendidikan dalam Tradisi Ya Qowiyyu Di Desa Jatinom Kecamatan Jatinom Kabupaten Klaten Tahun 2014. Disertation.

Tohmo, T. (2005). Economic Impacts of Cultural Events on Local Economies: An InputOutput Analysis of the Kaustinen Folk Music Festival. Tourism Economics, 11(3), 431-451.

Tyrrell, B. J., \& ISMAIL, J. A. (2005). A methodology for estimating the attendance and economic impact of an open-gate festival. Event Management, 9(3), 111-118.

UNWTO. (2019). Sustainable Development of Tourism. Retrieved November 5, 2019, from The World Tourism Organization website:

https://sdt.unwto.org/content/about-us-5
Wiseman, J., \& Brasher, K. (2008). Community wellbeing in an unwell world: Trends, challenges, and possibilities. Journal of Public Health Policy, 29(3), 353-366. https://doi.org/10.1057/jphp.2008.16

Yin Robert, K. (1994). Case study research: design and methods. Sage Publications.

Yolal, M., Gursoy, D., \& Uysal, M. (2016). Annals of Tourism Research Impacts of festivals and events on residents'. 61, 1-3 